Table 1. Age-matched comparisons across diagnoses

\begin{tabular}{|c|c|c|c|c|c|c|c|c|c|c|c|}
\hline & Gout & PsA & RA & AS & $\begin{array}{l}p- \\
\text { value }\end{array}$ & $\begin{array}{l}\mathrm{p} \text {-value } \\
\text { Gout }\end{array}$ & $\begin{array}{l}\text { ep-value } \\
\text { Gout }\end{array}$ & $\begin{array}{l}\text { p-val } \\
\text { Gout }\end{array}$ & $\begin{array}{l}\text { p-val } \\
\text { s PsA }\end{array}$ & $\begin{array}{l}\text { ep-va } \\
\text { s PsA }\end{array}$ & $\begin{array}{l}\text { ep-value } \\
\text { s RA v }\end{array}$ \\
\hline & & & & & & vs PsA & vs RA & AS & $\mathrm{RA}$ & AS & AS \\
\hline Total (n) & 249 & 249 & 249 & 249 & $\mathrm{~N} / \mathrm{A}$ & & & & & & \\
\hline $\begin{array}{l}\text { Age, mean } \\
\text { (SD) }\end{array}$ & $\begin{array}{l}62.5 \\
(11.2)\end{array}$ & $\begin{array}{l}64.2 \\
(10.2)\end{array}$ & $\begin{array}{l}63.1 \\
(11.6)\end{array}$ & $\begin{array}{l}62.8 \\
(10.5)\end{array}$ & NS & & & & & & \\
\hline $\begin{array}{l}\text { Education } \\
\leq 12 \text { years, } \\
\mathrm{n}(\%)\end{array}$ & $\begin{array}{l}132 \\
(53.0)\end{array}$ & $\begin{array}{l}148 \\
(59.4)\end{array}$ & $\begin{array}{l}160 \\
(64.3)\end{array}$ & $\begin{array}{l}139 \\
(55.8)\end{array}$ & NS & & & & & & \\
\hline $\begin{array}{l}\mathrm{HAQ} \text {, mean } \\
\text { (SD) }\end{array}$ & $\begin{array}{l}0.19 \\
(0.40)\end{array}$ & $\begin{array}{l}0.48 \\
(0.55)\end{array}$ & $\begin{array}{l}0.60 \\
(0.63)\end{array}$ & $\begin{array}{l}0.58 \\
(0.58)\end{array}$ & *** & 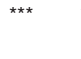 & $\star * \star *$ & $\star \star \star *$ & NS & NS & NS \\
\hline $\begin{array}{l}\text { VAS General } \\
\text { Health, } \\
\text { mean (SD) }\end{array}$ & $\begin{array}{l}2.6 \\
(2.3)\end{array}$ & $\begin{array}{l}3.7 \\
(2.4)\end{array}$ & $\begin{array}{l}3.8 \\
(2.6)\end{array}$ & $\begin{array}{l}4.0 \\
(2.3)\end{array}$ & *** & 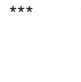 & 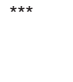 & 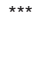 & NS & NS & NS \\
\hline $\begin{array}{l}\text { VAS Pain, } \\
\text { mean (SD) }\end{array}$ & $\begin{array}{l}2.6 \\
(2.4)\end{array}$ & $\begin{array}{l}4.0 \\
(2.6)\end{array}$ & $\begin{array}{l}3.8 \\
(2.6)\end{array}$ & $\begin{array}{l}4.2 \\
(2.4)\end{array}$ & 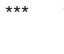 & $* \star \star$ & 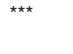 & 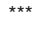 & NS & NS & NS \\
\hline $\begin{array}{l}\text { VAS Fatigue, } \\
\text { mean (SD) }\end{array}$ & $\begin{array}{l}3.6 \\
(2.6)\end{array}$ & $\begin{array}{l}4.5 \\
(2.7)\end{array}$ & $\begin{array}{l}4.3 \\
(2.6)\end{array}$ & $\begin{array}{l}4.9 \\
(2.5)\end{array}$ & 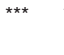 & $* * \star$ & * & $\star \star \star *$ & NS & NS & * \\
\hline \multicolumn{12}{|c|}{$\begin{array}{l}\text { SF-36 } \\
\text { domains, } \\
\text { median (IQR) }\end{array}$} \\
\hline $\begin{array}{l}\text { Physical } \\
\text { function }\end{array}$ & $\begin{array}{l}90.0 \\
(75.0- \\
95.0)\end{array}$ & $\begin{array}{l}70.0 \\
-(51.3- \\
95.0)\end{array}$ & $\begin{array}{l}70.0 \\
(45.0- \\
90.0)\end{array}$ & $\begin{array}{l}75.0 * \\
-(50.0- \\
90.0)\end{array}$ & *** & 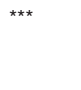 & 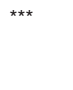 & $\star \star \star$ & NS & NS & NS \\
\hline Role physical & $\begin{array}{l}100.0 \\
(33.3- \\
100.0)\end{array}$ & $\begin{array}{l}50.0 \\
-(0.0- \\
100.0)\end{array}$ & $\begin{array}{l}50.0 \\
(0.0- \\
100.0)\end{array}$ & $\begin{array}{l}50.0 \\
(0.0- \\
100.0)\end{array}$ & *** & 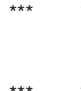 & 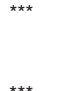 & $\star \star \star$ & NS & NS & NS \\
\hline Bodily pain & $\begin{array}{l}72.0 \\
(42.0- \\
100.0)\end{array}$ & $\begin{array}{r}52.0 \\
-(41.0- \\
74.0)\end{array}$ & $\begin{array}{l}52.0 \\
(41.0- \\
74.0)\end{array}$ & $\begin{array}{l}52.0 * \\
-(41.0- \\
64.0)\end{array}$ & *** & 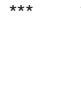 & 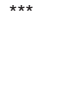 & 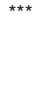 & NS & NS & NS \\
\hline $\begin{array}{l}\text { General } \\
\text { Health }\end{array}$ & $\begin{array}{l}67.0 \\
(47.8- \\
80.8)\end{array}$ & $\begin{array}{l}56.0 \\
(35.0- \\
72.0)\end{array}$ & $\begin{array}{l}55.0 \\
-(37.0- \\
72.0)\end{array}$ & $\begin{array}{l}50.0 * \\
(35.0- \\
71.0)\end{array}$ & *** & 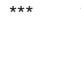 & 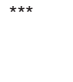 & 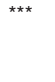 & NS & NS & NS \\
\hline Vitality & $\begin{array}{l}65.0 \\
(50.0- \\
77.5)\end{array}$ & $\begin{array}{l}57.5 \\
-(37.5- \\
75.0)\end{array}$ & $\begin{array}{l}57.5 \\
(42.5- \\
72.5)\end{array}$ & $\begin{array}{l}50.0 * \\
-(32.5- \\
70.0)\end{array}$ & *** & * & * & 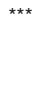 & NS & NS & NS \\
\hline $\begin{array}{l}\text { Social } \\
\quad \text { function }\end{array}$ & $\begin{array}{l}100.0 \\
(68.8- \\
100.0)\end{array}$ & $\begin{array}{l}81.3 \\
-(57.8- \\
100.0)\end{array}$ & $\begin{array}{l}81.3 \\
(67.2- \\
100.0)\end{array}$ & $\begin{array}{l}81.3 \text { * } \\
(50.0- \\
100.0)\end{array}$ & *** & $\star *$ & $\star \star$ & $\star \star \star$ & NS & NS & NS \\
\hline $\begin{array}{l}\text { Role } \\
\text { emotional }\end{array}$ & $\begin{array}{l}100.0 \\
(66.7- \\
100.0)\end{array}$ & $\begin{array}{l}100.0 \\
(33.3- \\
100.0)\end{array}$ & $\begin{array}{r}100.0 \\
-(33.3- \\
100.0)\end{array}$ & $\begin{array}{l}100.0 \text { * } \\
-(33.3- \\
100.0)\end{array}$ & & NS & $\star \star$ & $\star \star$ & NS & NS & NS \\
\hline Mental health & $\begin{array}{l}82.0 \\
(66.0- \\
92.0)\end{array}$ & $\begin{array}{l}78.0 \\
-(60.0- \\
92.0)\end{array}$ & $\begin{array}{l}78.0 \\
(60.0- \\
92.0)\end{array}$ & $\begin{array}{l}73.0 \text { * } \\
-(60.0- \\
88.0)\end{array}$ & & NS & * & 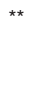 & NS & NS & NS \\
\hline \multicolumn{12}{|c|}{$\begin{array}{l}\text { SF-36 } \\
\text { summary } \\
\text { scores, } \\
\text { median (IQR) }\end{array}$} \\
\hline $\begin{array}{l}\text { Physical } \\
\text { component }\end{array}$ & $\begin{array}{l}48.4 \\
t(38.8-\end{array}$ & $\begin{array}{l}40.2 \\
-(28.5-\end{array}$ & $\begin{array}{l}40.2 \\
-(28.2-\end{array}$ & $\begin{aligned} & 38.7 \text { * } \\
- & (30.1-\end{aligned}$ & *** & 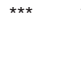 & 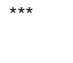 & 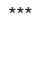 & NS & NS & NS \\
\hline $\begin{array}{l}\text { score } \\
\text { Mental }\end{array}$ & $\begin{array}{l}54.7) \\
51.7\end{array}$ & $\begin{array}{l}50.2) \\
51.0\end{array}$ & $\begin{array}{l}49.0) \\
50.7\end{array}$ & $\begin{array}{l}48.2) \\
47.7\end{array}$ * & * & NS & NS & * & NS & NS & NS \\
\hline $\begin{array}{l}\text { component } \\
\text { score }\end{array}$ & $\begin{array}{c}t(43.7- \\
56.5)\end{array}$ & $\begin{array}{l}(39.2- \\
56.4)\end{array}$ & $\begin{array}{l}-(39.6- \\
56.3)\end{array}$ & $\begin{array}{l}-(37.1- \\
55.3)\end{array}$ & & & & & & & \\
\hline
\end{tabular}

$\mathrm{HAQ}=$ Health Assessment questionnairel $\mathrm{RQ}=$ Interquartile range $\mathrm{SD}=\mathrm{Standard}$ deviationVAS $=$ Visual Analogue ScaleNS $=$ non-significant ${ }^{*}=$ significant at $\mathrm{p}<0.05^{* *}=$ significant at $\mathrm{p}<0.01^{\star \star \star}=$ significant at $\mathrm{p}<0.001$

Disclosure of Interests: None declared.

DOI: 10.1136/annrheumdis-2021-eular.1582

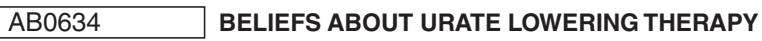 DIFFER BETWEEN GENERAL PRACTITIONERS AND RHEUMATOLOGISTS}

F. Veenstra $^{1}$, J. Vriezekolk' ${ }^{1}$ H. J. Schers ${ }^{2}$, N. Van Herwaarden ${ }^{1,3}$, B. Van den Bemt ${ }^{4,5}$, M. Flendrie'. ' Sint Maartenskliniek, Rheumatology, Ubbergen, Netherlands; ${ }^{2}$ Radboud University Medical Center, Primary and Community Care, Nijmegen, Netherlands; ${ }^{3}$ Radboud University Medical Center, Rheumatology, Nijmegen, Netherlands; ${ }^{4}$ Sint Maartenskliniek, Rheumatology \& Pharmacy, Ubbergen, Netherlands; ${ }^{5}$ Radboud University Medical Center, Pharmacy, Nijmegen, Netherlands

Background: Uric acid lowering therapy (ULT) can be effective in gout if taken correctly (1), but non-adherence is a known problem (2). Although patients' adherence barriers regarding ULT, such as lack of knowledge on disease and therapy, and beliefs, have been widely studied (3), less is known physicians' beliefs.

Objectives: To investigate the physicians' beliefs on ULT treatment in both primary and secondary care in the Netherlands.

Methods: Cross-sectional study among all rheumatologists of the Sint Maartenskliniek and to all General Practitioners (GPs) of 17 practices, participating in the practice-based research network Family Medicine Network Nijmegen,
Netherlands. All participants filled out the beliefs about medication questionnaire (BMQ), adjusted for physicians; in addition data were collected on physician characteristics including working experience in total and gout consultations. The BMQ consists of two parts, a specific part with 10 questions about beliefs on necessity $(\mathrm{N}=5)$ and concerns $(\mathrm{N}=5)$ regarding ULT and a general part with 8 questions about beliefs on harms $(\mathrm{N}=4)$ and overuse $(\mathrm{N}=4)$ regarding medication in general Each question is scored on a Likert-scale from 1-5, a higher score corresponds to higher beliefs on that category. Sum scores for all four categories were calculated. With the total scores on the specific $B M Q$ including necessity and concerns beliefs, physicians were classified in four different categories (Table 1)(4).

Results: In total 112 physicians received the questionnaire, 28 of 37 rheumatologists $(76 \%)$ and 45 of 75 GPs $(60 \%)$ responded. Rheumatologists had less years of experience than GPs (median 8.5 years (IQR $3-14$ ) versus (vs) 13 years (IQR 8-20)) and less hours of patient contact per week (15 hours (IQR $8.5-20$ ) vs 24 hours (IQR $20-30)$ ). Rheumatologists reported more consultations for gout per week than GPs: median 4 (IQR 1 - 6.6) vs 1 (IQR 0.2-1).

Rheumatologists scored higher on the BMQ necessity scale, 17.5 (95\% Cl 16.6 - 18.5) compared to GPs 16.1 (95\% Cl 15.1 - 17.1). GPs scored higher on BMQ concern scale, $12.1(95 \% \mathrm{Cl} 11.4-12.7)$ compared to rheumatologists, 10.4 (95\% Cl 9.7 - 11.2). On medication in general, GPs scored higher on both overuse and harms scales compared to rheumatologists, $11.3(95 \% \mathrm{Cl} 10.7-$ 12) versus $9.9(95 \% \mathrm{Cl} 9-10.7)$ and $8.3(95 \% \mathrm{Cl} 7.9-8.7)$ vs $7.1(95 \% \mathrm{Cl} 6.5$ $-7.7)$, respectively. Table 1 shows classification according to the BMQ specific for both groups.

Table 1. Classification based on the adapted BMQ

\begin{tabular}{lll}
\hline & Rheumatologists (N=28) & $\begin{array}{l}\text { GPs } \\
(\mathrm{N}=45)\end{array}$ \\
\hline Acceptant (\%) & $19(67.9)$ & $16(35.6)$ \\
Ambivalent (\%) & 0 & $8(17.8)$ \\
Sceptic (\%) & $1(3.6)$ & $5(11.1)$ \\
Indifferent (\%) & $8(28.6)$ & $16(35.6)$ \\
\hline
\end{tabular}

Conclusion: For the majority of rheumatologist the necessity beliefs outweighs concern beliefs towards the use of ULT outweighs concern beliefs. GPs show a more heterogenic profile, including acceptant, indifferent and ambivalent beliefs towards ULT use. GPs also show higher harm and overuse concerns regarding medication in general. Next step is to investigate possible associations with actual ULT use and disease outcome.

REFERENCES:

[1] Doherty M, et al. Lancet (London, England). 2018;392(10156):1403-12.

[2] Reach G. Joint, bone, spine: revue du rhumatisme. 2011;78(5):456-9.

[3] Harrold LR et al. Chronic illness. 2010;6(4):263-71.

[4] Toelichting BMQ. [updated 2011-12-10; cited 2021-01-28] Available trough: https://meetinstrumentenzorg.nl/instrumenten/beliefs-about-medicine -questionnaire-bmq-bmq-specific-bmq-general/

Acknowledgements: This study is sponsored by Grünenthal

Disclosure of Interests: Frouwke Veenstra: None declared., Johanna Vriezekolk: None declared., Henk J Schers: None declared., Noortje van Herwaarden: None declared., Bart van den Bemt Speakers bureau: Pfizer, AbbVie, UCB, Biogen and Sandoz, Consultant of: Delivered consultancy work for UCB, Novartis and Pfizer, Grant/research support from: UCB, Pfizer and Abbvie, Marcel Flendrie Consultant of: M. Flendrie has received consultancy fees from Menarini and Grunenthal., Grant/ research support from: M. Flendrie has received grants from Menarini and Grunenthal. DOI: 10.1136/annrheumdis-2021-eular.1834

\section{AB0635 INDEX BY CAROTID DOPPLER IN PATIENTS WITH MONOSODIUM URATE DEPOSITION ARTHRITIS OF THE HOSPITAL DOCENTE PADRE BILLINI, DOMINICAN REPUBLIC}

A. Cornelio ${ }^{1,2}$, J. Santana Peralta ${ }^{2}$, T. Polanco Mora ${ }^{2}$, Y. Cruz ${ }^{2}$, E. Rodriguez Bautista $^{2}$, T. Valdez ${ }^{2}$, R. Muñoz ${ }^{2}$, A. Feriz ${ }^{2}{ }^{1}$ Hospital Docente Padre Billini, Reumatologia, Santo Domingo, Dominican Republic; ${ }^{1}$ Hospital Docente Padre Billini, Reumatologia, Santo Domingo, Dominican Republic

Background: Hyperuricemia and gout are risk factors for atherosclerosis subclinical and cardiovascular complications. (1) However, it is still debated whether uric acid is an independent predictor of cardiovascular risk. (2) Vascular Doppler and in particular the measurement of the intima-media thickness and the detection of plaques are useful in the evaluation of cerebrovascular disease and cardiovascular risk. (3) An intima-media thickness greater than $0.9 \mathrm{~mm}$ and / or the presence of atheromatous plaques in the carotid are predictive of high cardiovascular risk and silent heart disease. (4) Gouty arthritis has been associated with alteration of the carotid intima media thickness (cIMT) and subclinical atherosclerosis. Cukurova et al studied patients with gout, finding an increase in cIMT compared to patients with asymptomatic hyperuricemia. (5)

Objectives: Assess the carotid intima-media thickness in patients with monosodium urate deposits arthritis 
Methods: Prospective, observational, cross-sectional study. Carotid Doppler was performed on patients in the outpatient clinic with a diagnosis of gout from November 2019 to 2020 of the rheumatology service of the Hospital Docente Padre Billini and healthy controls. Inclusion criteria, patients> 18 years, diagnosis of monosodium urate deposits arthritis according to the ACR / EULAR 2015 classification criteria, carotid Doppler, measurement of the cIMT. Controls without disease, matched by sex and age. The data was analyzed with SPSS V23 for Windows 10. Results: Of 37 patients with a diagnosis of arthritis due to deposition of monosodium urate crystals, (34) met inclusion criteria, 100\% male, 34 healthy controls. Average of 61.5 years. Average of the disease 8.2 years. Distribution $61 \%$ (21) intercritical gout, 32\% (11) chronic tophaceous gout, $0.5 \%(2)$ acute gouty arthritis. Comorbidities 67\% (23) dyslipidemia, 35\% (12) hyperglycemia. 26\% (9) presented arterial hypertension. 20\% (7) have diabetes mellitus. 58\% (20) are alcohol drinkers, $11 \%$ (4) smokers. Mean uric acid $8.6 \mathrm{mg} / \mathrm{dl}$ at Doppler, $52 \%$ (18) elevated serum creatinine. Carotid Doppler in patients with gout showed a $55 \%$ (19) increase in the cIMT > $0.9 \mathrm{~mm}$, with a mean of $2.03 \mathrm{~mm}$ (1.95 SD). Carotid Doppler in healthy controls $17 \%$ (6) increased cIMT, mean of $1.8 \mathrm{~mm}(2.2$ SD) $(P=0.040)$. Patients with gout had $29 \%(10)$ atheromatous plaques, $17 \%$ (6) calcified plaques versus $14 \%$ (5) atheromatous plaques, $8 \%(3)$ calcified in healthy controls.

Conclusion: Our study showed that half of the patients with gout had increased cIMT compared to a third of the healthy controls. The presence of atheromatous and calcified plaques was mainly associated with dyslipidemia, so we can conclude that the evaluation of the intima-media thickness by carotid Doppler allows it to be a predictor of cardiovascular disease in patients with gout.

REFERENCES:

[1] Choi HK, Curhan G (2007) Independent impact of gout on mortality and risk for coronary heart disease. Circulation 116:894-900

[2] Feig DI, Kang DH, Johnson RJ (2008) Uric acid and cardiovascular risk. N Engl J Med 359:1811-1821

[3] Choi, HK. Rho, Y-H., Zhu, Y., Cea-Soriano, L., Aviña-Zubieta, JA. Zhang, Y. The risk of pulmonary embolism and deep vein thrombosis in rheumatoid arthritis: A UK population-based outpatient cohort study. Ann Rheum Dis. 2013; 72 (7): 1182-7

[4] Gkaliagkousi, E., Gavriilaki, E., Doumas, M., Petidis, K., Aslanidis, S., Stella, D. Cardiovascular risk in rheumatoid arthritis: Pathogenesis, diagnosis, and management. J ClinRheumatolPract Rep Rheum Musculoskelet Dis. 2012; 18 (8): $422-30$

[5] Cukurova S, Pamuk ÖN, Ünlü E, Pamuk GE, C, akir N. Subclinical atherosclerosis in gouty arthritis patients: a comparative study. Rheumatol Int. 2012; 32(6):1769-73.

Disclosure of Interests: None declared.

DOI: 10.1136/annrheumdis-2021-eular.2747

\section{AB0636 ASYMPTOMATIC HYPERURICEMIA IN INFLAMMATORY RHEUMATIC DISEASES}

A. Fonturenko ${ }^{1}$, R. Bashkinov ${ }^{1,2}$, V. Mazurov ${ }^{1,2}$, M. Petrova ${ }^{2,3}$, O. Inamova ${ }^{2,3}$, I. Gaydukova ${ }^{1,2}$. 'Clinical Rheumatological Hospital No25, Center for diagnosis and treatment of autoimmune diseases, Saint-Petersburg, Russian Federation; ${ }^{2}$ North-Western State Medical University named after II Mechnikov, Department of Therapy, Rheumatology, Examination of Temporary Disability and Quality of Medical Care named after E. E. Eichwald, Saint-Petersburg, Russian Federation; ${ }^{3}$ Clinical Rheumatological Hospital No25, City Clinical Center of Gout, Saint-Petersburg, Russian Federation

Background: Uric acid (UA) is well-known biomarker of cardiovascular risk and inflammation. However, the data about interrelations between asymptomatic hyperuricemia $(\mathrm{AHU})$ and rheumatic diseases $(\mathrm{RD})$ are limited and contradictory [1]. Objectives: to identify the occurrence of $\mathrm{AHU}$ in pts with different RD and to evaluate the interrelations between the AHU and clinical features of the RD. Methods: The study included data from 822 pts with AHU and RD involved in the Saint-Petersburg Register of Pts with AHU in period from the 01jan2000 to the 01apr2020. The AHU was defined as the serum level of uric acid (UA) that exceeded $360 \mu \mathrm{mol} / \mathrm{l}$ without signs of gouty arthritis. Pts with the secondary reasons of $\mathrm{AHU}$ (an oncologic diseases, late stages of chronic kidney disease, ets), and inflammatory diseases another than RD were excluded from the study.

Patient's demographical characteristics, duration of AHU, level of UA, activity of RD, ESR, CRP, urate-lowering therapy (ULT) were analyzed. The study was approved by local ethic committee. Statistics was performed with SPSS17.

Results: Characteristics of the Patients with the RD and $\mathrm{AHU}$ are present in Table 1. The duration of $A H U$ in pts with the RD was $3.4 \pm 3.4$ [0.08-18] years, mean duration of follow-up $2.7 \pm 4.0$ years, mean number of visits during the period of follow-up was $3,2[\min 1$; $\max 7]$, ESR $26.0 \pm 14.1 \mathrm{~mm} / \mathrm{h}$, CRP $19.6 \pm 21.0 \mathrm{mg} / \mathrm{l}$
Table 1. Characteristics of the Patients with the Rheumatic diseases and asymptomatic hyperuricemia.

\begin{tabular}{lllll}
\hline & $\begin{array}{l}\text { Age, years } \\
\text { (Mean } \pm \text { SD) }\end{array}$ & Male, \%** & $\begin{array}{l}\text { Serum UA, } \mu \text { mol/l l } \\
(\text { Mean } \pm \text { SD) }\end{array}$ & $\begin{array}{l}\text { Normalization of UA during } \\
\text { the follow-up, } n(\%)\end{array}$ \\
\hline $\mathrm{RD}, \mathrm{n}=822$ & $56.7 \pm 14.5$ & 40.27 & $493.3 \pm 98.5$ & $242(29.44)^{\# \#}$ \\
$\mathrm{RA}, \mathrm{n}=329$ & $64.2 \pm 12.1$ & 3.74 & $504.8 \pm 107.5^{\#}$ & $99(30.09)^{\# \#}$ \\
$\mathrm{PsA}, \mathrm{n}=149$ & $56.6 \pm 12.9$ & 53.69 & $531.5 \pm 94.9^{\#}$ & $32(21.48)^{\# \#}$ \\
$\mathrm{SpA}, \mathrm{n}=107$ & $45.6 \pm 15.1^{\star}$ & 33.43 & $520.8 \pm 86.5^{\#}$ & $18(16.82)^{\# \#}$ \\
$\mathrm{SLE}, \mathrm{n}=137$ & $50.3 \pm 14.1^{*}$ & 20.44 & $451.6 \pm 91.4$ & $57(41.61)$ \\
$\mathrm{SSc}, \mathrm{n}=57$ & $61.0 \pm 12.4$ & 22.81 & $456.2 \pm 99.5$ & $20(35.09)$ \\
$\mathrm{SD}, \mathrm{n}=43$ & $62.0 \pm 10.7$ & 16.28 & $442.4 \pm 107.5$ & $16(37.21)$ \\
\hline
\end{tabular}

$\mathrm{RD}$ - rheumatic disease; RA — rheumatoid arthritis; PsA — psoriatic arthritis; SpA — spondy loarthritis; SLE — systemic lupus erythematosus; SSc — systemic sclerosis; SD — Sjogren's disease; * $-p<0.001$ for the differences with RD, RA, PsA, SSc, SD; ${ }^{* *}-p<0.01$ for all intergroup differences; ${ }^{\#}-p<0.01$ for the differences with RD, RA, SSc, SD; $\#-p<0.01$ for the differences with RA, SSc, SD.

Were revealed the interrelations between the level of UA and ESR (Spearmen's $\mathrm{R}=0.1, \mathrm{p}=0.01$ ), and UA and CRP (Spearmen's $\mathrm{R}=0.12, \mathrm{p}=0.001$ )

The level of UA in male pts was 507.0 [361-940], in female pts 450.0 [361-1010] $\mu \mathrm{mol} / \mathrm{A}$ ( $p<0.0001$ ), in SLE pts with elevated anti-nuclear factor (ANF) UA was 429 [361-940] and with normal 494 [361-973] $(\mathrm{p}<0.0001)$. In pts with high and low RD activity UA was 490 [361940] and 454 [363-1010]) $\mu \mathrm{mol} / \mathrm{r}$ respectively, $(p<0.0001)$. The higher UA level was found in any $\mathrm{RD}$ as compared with UA in low activity of the same $\mathrm{RD}$ ( $\mathrm{p}<0.0001$ for all the differences). Normalization of UA was found in $243(29.6 \%)$ pts, lack of normalization of UA in $434(52.8 \%)$ of cases, $n=677$, Table 1 . ULT received $219(26.6 \%)$ pts. Normalization of UA without ULT was registered in 16 (1.9\%) of the pts.

Conclusion: UA level is higher and normalize less often in patients with $\mathrm{SpA}$ and PsA as compered with RA, SLA, SSc and SD pts. In any of analyzed rheumatic diseases the level of UA is higher in male pts and in pts with high disease activity. REFERENCES:

[1] K.Bosmansky, M. Ondrasik. Ter Arkh.1987;59(4):22-5

Disclosure of Interests: None declared.

DOI: 10.1136/annrheumdis-2021-eular.2980

\section{\begin{tabular}{|l|} 
AB0637 THE STATE OF GOUT MANAGEMENT IN WALES \\
\hline
\end{tabular} RHEUMATOLOGY UNITS}

\section{Saleh ${ }^{1} .{ }^{1}$ University Hospital of Wales, Rheumatology, Cardiff, United Kingdom}

Background: Gout is the most common inflammatory arthritis with both the prevalence and incidence showed significant rise in the UK in recent years ${ }^{1}$.

The most frequent reasons for referral from primary care were diagnostic uncertainty $54 \%$, failure to respond to primary care management $28 \%$, and complex comorbidity $25 \%{ }^{2}$.

From primary care perspective, increased urate level $(p=0.0001)$, young age $(p=0.009)$, fewer comorbidities $(p=0.039)$ constituted the most common risk for gout General Practice consultations and in addition to poor compliance to urate lowering treatment ULT $(p=0.004)$ and lower CVS risk scores $(p=0.038)$ these all factors comprised the independent risk factors for Gout flares ${ }^{3}$

Objectives: To compare the management of gout in the rheumatology services in Wales against the 2017 British Society for Rheumatology (BSR) Guidelines.

Methods: •A descriptive study over an 8-week period from January to February 2019, used Simple Analysis in calculating the frequency (\%).

-Data were collected from notes of 79 patients referred to rheumatology departments across Wales using the British Society for Rheumatology (BSR) 2017 Gout Guidelines Audit Tool.

-The audit cohort comprised $62 \%$ of chronic gout patients and $38 \%$ of acute admissions

Results:

\begin{tabular}{|l|l|l|}
\hline Gout Audit & $\begin{array}{l}\text { All Wales 2019 } \\
\text { (BSR Guidelines 2017) }\end{array}$ & $\begin{array}{l}\text { UK National Audit } \\
\text { (BSR Guidelines 2007) }\end{array}$ \\
\hline Education material & $54 \%$ & No available data \\
\hline Newly start ULT & $59 \%$ & $42 \%$ \\
\hline ULT was prescribed & $87 \%$ & $33 \%$ \\
\hline ULT was continued & $78 \%$ & $76 \%$ \\
\hline Prophylaxis & $94 \%$ & $94 \%$ \\
\hline Febuxostat & $21 \%$ & $10 \%$ \\
\hline ULT main indication & $>2$ attacks (71\%) & Tophi (81\%) \\
\hline eGFR $<60$ ml/min & $40 \%$ & $30 \%$ \\
\hline Urate level checked & $83 \%$ & $72 \%$ \\
\hline Urate $<300$ umol/L & $36 \%$ & $25 \%$ \\
\hline Urate $<360$ umol/L & $58 \%$ & $45 \%$ \\
\hline
\end{tabular}

